\title{
Assessment of Tourism Potential in Thane District, Maharashtra, India
}

\author{
Rajendra S. Suryawanshi \\ Associate Professor \& Head, Department of Geography, Abasaheb Garware College, Karve Road, University \\ of Pune, Pune .Maharashtra, India,
}

\begin{abstract}
This study is carried out to analyze the potential of tourism in Thane district of Maharashtra. The types of tourism are landscape, landform and cultural. The weights were assigned to the village polygons on the basis of the value of variables. The weights assigned range from 1 to 5. Using these weights a composite index for aerial differentiation based on the physical factors was defined. For site specific aspect the exercise was repeated taking into account the locations of specific landforms that could attract the tourists. One can assess the places on a scale ranging from average, normal, different, distinct unique. Composite index to determine the tourism potentials for the places or regions in the area under consideration
\end{abstract}

Keywords: Tourism potentials Composite Index, GIS Application.

\section{Introduction}

The tourism is an activity that involves three components such as the tourist (the visitor or service seeker), the personnel involved in catering to the needs of tourists (the service providers) and the place(s) of interest. Among these components, the place (or the region) is significantly important for deciding the scope of tourism in any area. The next aspect that one needs to take into consideration is the tourist. Wherefrom the region will get the visitors? The local population may not always be the target group. This may be because of a number of factors including the socio-economic set up of the local population. The service providers can be the last on the list because unless the potentials of the region are realised and the target population identified the tourism activity cannot start.

If we think in terms of cultural tourism, a temple or a church; or any place of worship can be a place of tourist destination. The temple with some mythological importance like Jyotirlingas, or faith of people at large about the specific place of worship that attracts large number of devotees to such few places e.g. Hazi Malang Dargah appear to be the factor that makes a centre the place of tourist attraction. A historical place such as a palace or a fort also could be considered as a tourist attraction place. After the fall of Maratha Power in Maharashtra many forts remained un-noticed for long period of time. It was only after efforts by some leaders, the history of the forts got revived in the minds of people that made these forts become the centres regional pride and subsequently the centres of tourist attraction. Monuments particularly erected in the recent past like the Gateway of India in Mumbai or the Victoria memorial Hall in Kolkata or the Vivekananda Rock at Kanyakumari can be considered as the centres of tourist attractions. Besides these, certain museums developed in recent years like the Vishwesharayya Industrial Museum of Bangalore become the centres of the tourist attraction mainly because of the fact that they are quite different than other places.

In case of natural tourism wherein the landscape assumes greater importance the scope of tourism in a region mainly depends on the landscape diversity. The monotonous flat land may not attract the tourists, as much as a mountainous tract would do. A beach, a waterfall, a gorge, a peak becomes the point of attraction than a flat river plain. The forest land preferably with minimal of human interventions can be a place of attraction. Most of the tourists that prefer natural tourism over the cultural do so for the reason that they want to spend the available time in peace and would prefer moving away from the day to day stressful life. Hence a forest village or a solitary village in the mountainous tract would be the preferred destination for such tourists.

The sites of large dams, region of dam reservoirs, or the national parks and sanctuaries are the new tourist destination in the list centres for natural tourism. All these have high landscape diversity, bio diversity as well as the uniqueness, and it is these characteristics that make a place or a region centre of tourist attraction. Thus it may be summarised that for a place or a region to become a place of attraction what is needed is a distinctive character that is otherwise not available at the place of residence of the tourists. In the recent period a number of attempts have been made for the scenic evaluation of the landscape and for assessing the tourism potentials. Cook and Doornkamp (1974), Leopold (1969 a \& b), Linton (1968), Fines (1968) have attempted such type of research work and used various techniques of scenic evaluation. In addition to this, the work by Leitao (1997) on landscape capacity evaluation and visual simulation also provides some methodological aspect for analysing the landscape. With the availability of remotely sensed data as well as the GIS techniques the work 
of assessing the scenic beauty has become somewhat manageable, The FCCs provide good spatial distribution of forestlands as well as other landuse categories. The availability of elevation data facilitates the construction of DEM and has a visual representation of the landscape in the form of block diagrams.

One can assess the places on a scale ranging from average, normal, different, distinct unique. Such a grading can be assigned to a place on the basis of a single variable or for a group of variables and weights thus given can then be used for a composite index to determine the tourism potentials for the places or regions in the area under consideration.

For assessing the potentials of tourism for an area what is needed is to identify the possible centres or regions within the areas and determine if these have any uniqueness in themselves so as to become the possible centres of tourist attraction. It is the diversity, magnanimity, rarity; a legendary history, association of a place with some legendary personality etc which are the facts that attract the tourists to a given place. The centres or the regions that one considers to be having some potential to attract the tourists need to be assessed in terms of the above mentioned and similar characteristics.

Linton worked on areal differentiation and assigned values to parcels of areas on the basis of variables like relative relief, slope, frequency and depth of dissecting valleys isolation of hills from their neighbour etc. The attempt was purely in terms of areal classification based on landform characteristics. Linton also added a dimension of landuse to his system and classified the areas such as dull, ugly, depressing particularly those with high degree of urbanisation and industrial concentrations while the regions high relief, steep slopes, isolation from urbanised and industrial areas as the better areas in aesthetic scales.

\section{The Study Area}

The total geographical area of the Thane district is $9558 \mathrm{sq} \mathrm{km}$, accounting for $3.11 \%$ of the total geographical area of the State. Thane, the northern-most district of Konkan, lies adjoining the Arabian Sea in the northwestern part of Maharashtra State. The district extends between $18^{\circ} 42^{\prime}$ and $20^{\circ} 20^{\prime}$ North latitudes and from $72^{\circ} 45^{\prime}$ to $73^{\circ} 48^{\prime}$ East longitudes. It shares its northern border with the Valsad District which is a part of the State of Gujarat and Union territories of Dadra and Nagar Haveli. The districts of Nasik and Ahmednagar are to its East, Pune to the South-East, Raigad to the South and Mumbai Metropolitan to the South-West (Figure1).

\section{Research Methods}

For the regional landscape evaluation variables were taken into consideration are relative relief, mean slope, drainage density and forest cover. The data for the first three variables was collected from the topographical sheets $(1: 50,000)$ and the SRTM elevation data with $90 \mathrm{~m}$ (or 3minutes) ground resolution. The forest cover was obtained from the FCC using IRS LISS III data. Besides the FCC data the area under forest available from the revenue records was also used to obtain the distribution of forestland. The village polygons for 1748 villages were used as the areal units. The weights were assigned to the village polygons on the basis of the value of variables. Areas with 1) greater relative relief, 2) steeper slope and 3) higher drainage density as well as 4) proximity to the forested areas were assigned higher values. The weights assigned range from 1 to 5 . Using these weights a composite index for areal differentiation based on the physical factors was defined (Table-1).

For site specific aspect the exercise was repeated taking into account the locations of specific landforms that could attract the tourists. The landforms such as 1) water falls, 2) confluences of major rivers, gorges and meanders, 3) coastal exposures, 4) creeks and islands (both coastal and inland), 5) lakes, 6) cliffs (Maximum slope $>60^{\circ}$ ) etc. were identified from the topographical maps as well as DEMs developed using SRTM data. The villages where these landform are located as well as the villages within $3 \mathrm{~km}$ distance from these landforms have been identified as the regions of tourist interest. The weights were assigned to these locations and summed up to get a composite index.

The third group includes features of cultural importance like places of worship, forts, caves, springs (including the hot springs), locations of annual fairs, palace and hill-stations. In order to identify possible centres of tourist attraction information was collected from 1) Thane District Gazetteer (1982), topographical maps 1:50,000 and Suresh Paranjape's book on 'Sahali Ek Divasaachyaa Aaspaas Mumbaichyaa' (one day short tours around Mumbai) (2004). The villages within $3 \mathrm{~km}$ distance from the locations of the above-mentioned list have been identified and assigned weights.

While assessing the potentials of tourism it is necessary to take into account the infrastructure that is available in the region. Hence variable like 1) accessibility to Railways, National, State Highways and District Roads, 2) Government Accommodation in terms of rest houses, 3) Market Places, 4) Police Stations, 5) Commercial Banks, 6) Bus Service, 7) Primary Health Centres have been taken into consideration to assess the level of infrastructure in the District. The centres / regions with better infrastructure conditions. 
Apart from this various cartographic representations have been adopted. Most of the census and revenue data were analysed through Arc-GIS 9.1, Auto-Cad Map, Global Mapper, software besides MS Office Excel used for data processing.

\section{Tourism Potentials of Thane District:}

Considering the above methodology the potential for the tourism in Thane District was assessed on the basis of physical as well as cultural factors. The Urban Thane is a region that scores high in terms of developmental indices. Here while discussing the tourism potentials the emphasis is given on the Rural Thane in general and the tribal belt of the district in particular. The northern and the eastern parts of the district have high concentration of scheduled tribe population. The dominant tribes in the district are Warli, Mahadeo Koli, Malhar Koli, Thakar and Kokana.

\section{Landscape Evaluation}

\section{Natural Tourism}

The map shown in figure 2 is based on the composite weight assigned on the basis of relative relief, slope, drainage density and forest land. The relative relief and the slope best represent the relief diversity in a region. The area with high rises and steep slopes not only provoke the young minds for adventures but also attract the common tourist with its magnanimity. Thane has two such regions with high relief. One obviously is the Western Ghats escarpment in the east. The other region is the portion of coastal ranges. Though the total relative relief is not of high order the abrupt rise of the coastal range from the low lying coastal strip makes the range stand out distinctly in the entire region. Moreover the coastal range has dense patches of forest. Besides these two regions the western margin of the low lying plateau - the Wada-Mokhada plateau - also provides steep escarpment that has the potential to attract the minds of nature lovers. The areas of coastal range and Western Ghats region and the western margin of low-lying plateau stand out as the main regions of high tourism potentials. The patches of forestland not coinciding with these regions and located along the boundaries between Murbad-Kalyan and Murbad-Shahapur tahsils can be identified as a separate region.

\section{Landform Evaluation}

Site-specific locations of the landforms that have great potentials for tourism are generally missed in the attempt of landscape evaluation based on the area related data. A site with a deep gorge or a waterfall will attract more tourists than just a region of high relative relief. Hence in the scenic evaluation of a region one has to treat individual landforms separately. Therefore certain specific landforms that are spread over the entire region were identified and a separate composite index on the basis of weights given has been attempted. A list of the specific landforms considered is already given while discussing the methodology. The map shown in figure 3 identifies the areas of high tourism potentials based on the accessibility of specific landforms.

The coastal tract from Dahanu to Vasai tahsils stands out as a distinct region in the map. Besides being exposed to open sea the region has advantage of having creek locations as well as the marine and riverine islands. As mentioned above the much of the coast in this part is rocky and that too flat. Except for the Bordi beach in Dahanu tahsil there are hardly any long beaches. Nonetheless the creeks are navigable for 25 to $30 \mathrm{~km}$. Large permanent islands have been developed in the creek areas. There are saltpans in the Dahanu creek.

The second important region that gets identified is the Vada-Mokhada plateau, identified as a low-lying plateau while describing the physiography. A number of waterfalls are located in this region; Dabhosa falls with a drop of about $30 \mathrm{~m}$ is the most spectacular among them. The entire plateau has undulating topography. However, though being located in the high rainfall zone and adjacent to the Ghats it has sparse forest cover. This may be because of heavy erosion and poor soil cover in the area. Besides the waterfalls other landforms that need a mention in this area as well as at number of places in Thane district is the gorges and meandering courses of rivers. River Vagh, a tributary of Damanganga basin, has developed deep incised meanders that can attract the minds of tourists. The stretch of meanders of River Vagh for a distance of $12.1 \mathrm{~km}$. The meandering bed is about $400 \mathrm{~m}$ below the surrounding flat land with the valley side relief of $300 \mathrm{~m}$. From the vantage point in upstream direction the whole meandering course provides a splendid view. The point is located at a distance of $2.5 \mathrm{~km}$ from Mokhada town.

River Vaitarna collects it headwaters from the plateau area located above the Western Ghats scarp. This however administratively falls in the Nasik district. Nonetheless it is just adjacent to the district boundary. In its upper course a dam has been constructed and a large reservoir is created due to the same. Within just $7.5 \mathrm{~km}$ from the dam the river enters into a deep gorge while crossing the Western Ghats escarpment. Beyond this gorge the river continues to flow through a series of picturesque rocky gorges for a distance of $22.9 \mathrm{~km}$ with channel width of just not more that 15 to $20 \mathrm{~m}$. It is a treat to follow these gorges that which are not only deep and with near vertical banks but for most of the distance the river follows meandering path. Deep incised meander and 
gorges appears to be a characteristic feature of many rivers in Thane district. River Kalu a tributary from Ulhas basin, River Surya, a tributary of River Vaitarna also have similar meandering courses.

\section{Cultural Tourism}

The cultural tourism is basically site specific and mostly related to pilgrimage and historical monuments. However, besides these the local level annual fairs where people gather occasionally as well as the weekly markets where people frequently gather for trade also have sufficient potentials for development of tourism in a region. District Thane has a large number of such places where either at present people are visiting or the places are having some potentials to develop as tourist centres. Some of such centres are described below. (Figure 4)

\section{Port, Forts and Caves}

District Thane has a long history of being a major trading centre having contact with the outside world. Its present name 'THANE' meaning a place, stems from Sanskrit word 'ShriSthanak'. It had trade ties with the Greek - Roman Empire through the port "Shurparak", presently known as Sopara. It is situated in Vasai tahsil of the district. Shurparak was one of the leading settlements of north Konkan in historical period. The sea fort on Arnala Island off Vasai Coast is another historical place. The fort was built by Portuguese and was later conquered by Marathas under the leadership of Chimaji Appa, younger brother of Bajirao I. Thus the coastal Thane has a long history and this contributes to the potential of cultural tourism of the district in a big way. Besides the Sopara port and the Arnala Fort the coastal Thane has a number of other forts situated in Palghar and Dahanu tahsils. The coastal range also has small hill forts, mostly built to guard the coastal highway during the historical period as this was connecting the Sopara Port with the Gujrat area as well as the routes leading to Nasik. The second line fort is formed by Mahuli (near Asangaon) in Shahapur tahsil, Balwant Gad near Kasara in Shahapur tahsil and Bhupat Gad (Zaapcha Killa) near Khodala in Mokhada tahsil forts located along Shahapur-Jawahar route. The hill forts along the Ghats escarpment, namely Bhairav Gad (near Moroshi), Gorakh Gad (near Deheri) and Siddh Gad (near Mhasa) in Murbad tahsil form the third group. These forts are along the route joining Thane and Ahmednagar. Thane has comparatively fewer caves and these are located in two groups 1. The Dahanu - Palghar area and the second in the Ghats escarpment in Murbad tahsil close to Malshej Ghat location. These are rock cut caves mostly facilitating the travellers as the retiring rooms. Locally these are called 'Ganeshlene'. In Jawahar town there is a small palace called 'Jay Vilas palace' built by the King who were ruling the territory till recent past. A small museum is now developed in part of the palace and the same is made available for the visitors. This can be further strengthened and can become a place of attraction.

\section{Springs}

The geological structure of the region has provided the district with a number of hot-spring locations. The most famous and frequently visited by people among these are the hot springs at Vajreshwari temple located in Bhiwandi tahsil. The hot-springs water has some sulphur dissolved in it and hence people consider it to be one of the centres where skin diseases can get cured. Besides these there are hot springs at Manor in Palghar tahsil. In the northern and eastern Thane there are number of spring locations that form the sources of a few streams. These are of course not hot springs.

\section{Places of Worship}

There are numerous religious places scattered in the district. However, if we consider the ones that are frequented by people and are more popular we find a definite pattern. The important religious places are located on the three artilleries of the district 1. Thane-Surat Road, 2. Thane-Nasik Road and 3. Thane- KalyanAhmednagar Road. (Figure 5)

The important religious places in the district are Vajreshwari Temple in Bhiwandi tahsil, Titwala Temple in Kalyan tahsil, Mahalakshmi temple near Vivalvedhe (Charoti) of Dahanu tahsil Hazi Malang Dargah in Ambarnath tahsil and the Agashi in Vasai tahsil. Annual fairs in the district mostly occur in February March months. The most important tribal fair is held at Ajya Dongar (near Dolkhamb_) in Shahapur tahsil. This is a sacred place for Koli Tribe and particularly Mahadeo Kolis. In Mokhada tahsil a major event of 'Bohoda'. It is observed in the month of March that is attended by a large number of tribals particularly of Mahadeo Koli. .

\section{Tribal Culture of Thane}

Besides the places described above the tourism potentials of the district basically lie in the tribal culture of the region. The northern and north eastern part has sizable tribal population and many of the villages have more than $90 \%$ of tribal population. It is not a place in particular that can be named as to have tourism potentials. Here one has to think in terms of the region than a place. Dahanu, Talasari, Vikramgad, Wada, 
Jawahar and Mokhada tahsils can be identified as to be the regions with potentials of developing rural tourism with an emphasis on tribal culture. Tribal Tourism Toolkit, a document prepared by NATHPO (2002) outlines a strategy for assessing tribal tourism potentials. While it is true that the document was prepared for the development of tribal tourism in USA particularly targeting aboriginals, some of the aspects of the strategy can be applied in the Indian context. (Figure 6)

\section{Cultural festivals}

The response of local people is positive towards the tourism development. People believe that the physical features and tribal culture, art and craft have the potentials to attract the tourists, not only from adjoining regions of Maharashtra but also from the other parts of India and the world.

\section{Conclusion}

Thane district has high tourism potential in view of natural and cultural aspects. Northern part of Thane district is covered by rural area and also considered to be a tribal tract of the region. Such highly remote areas also have high potential of tourism in terms of various landscapes and landforms like waterfalls gorge. etc. Besides this, there is a potential of cultural tourism.

\section{References}

[1]. Cooke R. U and Doornkamp J.C. (1974), Geomorphology in Environmental Management- An Introduction, Clarendon Press. Oxford.

[2]. Countryside Commission for Scotland (1971), Planning Classification of Scotish Landscape Resources (C.C.S., Perth), Pp. 123, cf. Cooke R. U and Doornkamp J.C. (1974), Geomorphology in Environmental Management- An Introduction, Clarendon Press. Oxford.

[3]. Fines (1968), Landscape Evaluation: A Research Project in East Sussex, Regional Studies,2,41-55 cf. Cooke R. U and Doornkamp J.C. (1974), Geomorphology in Environmental Management- An Introduction, Clarendon Press. Oxford.

[4]. Gazetteer (2000), Gazetteer of the Bombay Presidency, Thana Places of Interest,

[5]. Vol.XIV, Government Central Press Mumbai

[6]. Leitão, A.B. (1997), Landscape capacity evaluation and visual impacts simulations a GIS approach. Proceedings of the 12th European ESRI User Conference Copenhagen.

[7]. Leopold (1969), a. Quantitative Comparison of Some Aesthetic Factors Among Rivers, U. S. Geological Survey, Circular, 620, Pp.16 cf. Cooke R. U and Doornkamp J.C., 1974. Geomorphology in Environmental Management- An Introduction, Clarendon Press. Oxford.

[8]. Leopold (1969), b. Landscape Aesthetics, Natural History (October), Pp.35 - 46. cf. Cooke R. U and Doornkamp J.C., 1974. Geomorphology in Environmental Management- An Introduction, Clarendon Press. Oxford.

[9]. Linton (1968), The Assessment of Scenery As a Natural Resource, Scottish Geog. Mag. 84, Pp. 218-38, cf. Cooke R. U and Doornkamp J.C., 1974. Geomorphology in Environmental Management- An Introduction, Clarendon Press. Oxford.

[10]. NATHPO (2002), Tribal Tourism Toolkit, Lewis \& Clark Bicentennial and other Tribal Opportunities, National Association of Tribal Historic Preservation Officers Washington,DC (accessed at http:/history.utah.gov/heritage_tourism_toolkit/general_information/tribaltourismtoolkit.html)

[11]. Paranjpe S. (2004), Sahali Ek Diwsachya Aspass Mumbaichya,published by Snehal Prakashan, Pune.

[12]. Suryawanshi R S. (2008), Tourism Potentials of Thane District: A Geographical Enquiry Unpublished Ph.D. Thesis, University of Pune

[13]. Suryawanshi R S. (2011), Landuse Landcover and Terrain Analysis for Eco-tourism in Talasari and Dhanu tahsils of Maharashtra., The Goa Geographers, Vol.VIII NO.1, P.P 08 to 19.

[14]. Suryawanshi R S. (2012), Assessment of Potential for Eco-Tourism, Northern Thane District, Maharashtra LAP LAMBERT Academic Publishing GmbH \& Co. KG Heinrich-Böcking-Str. 6-866121, Saarbrücken,

Table -1. Scores of Composite index for Tourism Potential

\begin{tabular}{|c|c|c|c|c|c|c|c|}
\hline Indicators & Variables & Unit & 01 & 02 & $\mathbf{0 3}$ & 04 & 05 \\
\hline \multirow{4}{*}{$\begin{array}{c}\text { 1 ) } \\
\text { Regional } \\
\text { Landscape } \\
\text { Evaluation }\end{array}$} & Relative Relief & Metres & $<50$ & $50-100$ & $100-250$ & $250-400$ & $>400$ \\
\hline & Mean Slope & Degree & $<3$ & $3-7$ & $7-15$ & $15-25$ & $>25$ \\
\hline & Drainage Density & $\mathrm{km} / \mathrm{sq} \cdot \mathrm{km}$ & $0-0.1$ & $0.1-0.4$ & $0.4-0.8$ & $0.8-1.4$ & $1.4-5.2$ \\
\hline & Forest Cover & Percentage & 0 & $1-30$ & $31-50$ & $51-80$ & $>80$ \\
\hline \multirow{6}{*}{$\begin{array}{c}\text { 2) } \\
\text { Landforms } \\
\text { Evaluation }\end{array}$} & Waterfalls & Villages within $3 \mathrm{KM}$ & & & & & $1 *$ \\
\hline & $\begin{array}{c}\text { Confluences of major rivers, } \\
\text { Gorges and meanders }\end{array}$ & Villages within $3 \mathrm{KM}$ & & & & & $1 *$ \\
\hline & Coastal exposures & Villages within $3 \mathrm{KM}$ & & & & & $1 *$ \\
\hline & $\begin{array}{l}\text { Creeks and islands(both Costal } \\
\text { and inland) }\end{array}$ & Villages within $3 \mathrm{KM}$ & & & & & $1 *$ \\
\hline & $\begin{array}{c}\text { Lakes } \\
\end{array}$ & Villages within $3 \mathrm{KM}$ & & & & & $1 *$ \\
\hline & Cliffs (Max. slop $>60$ & Villages within $3 \mathrm{KM}$ & & & & & $1 *$ \\
\hline \multirow{7}{*}{$\begin{array}{l}\text { 3) Cultural } \\
\text { Importance }\end{array}$} & Places of Worship & Villages within $3 \mathrm{KM}$ & & & & & $1 *$ \\
\hline & Forts & Villages within $3 \mathrm{KM}$ & & & & & $1 *$ \\
\hline & Caves & Villages within $3 \mathrm{KM}$ & & & & & $1 *$ \\
\hline & $\begin{array}{l}\text { Springs(including the hot } \\
\text { springs) }\end{array}$ & Villages within $3 \mathrm{KM}$ & & & & & $1 *$ \\
\hline & Location of annual fairs & Villages within $3 \mathrm{KM}$ & & & & & $1 *$ \\
\hline & Palace & Villages within $3 \mathrm{KM}$ & & & & & $1 *$ \\
\hline & Hill-stations & Villages within $3 \mathrm{KM}$ & & & & & $1 *$ \\
\hline
\end{tabular}

$1 *$ is Availability 

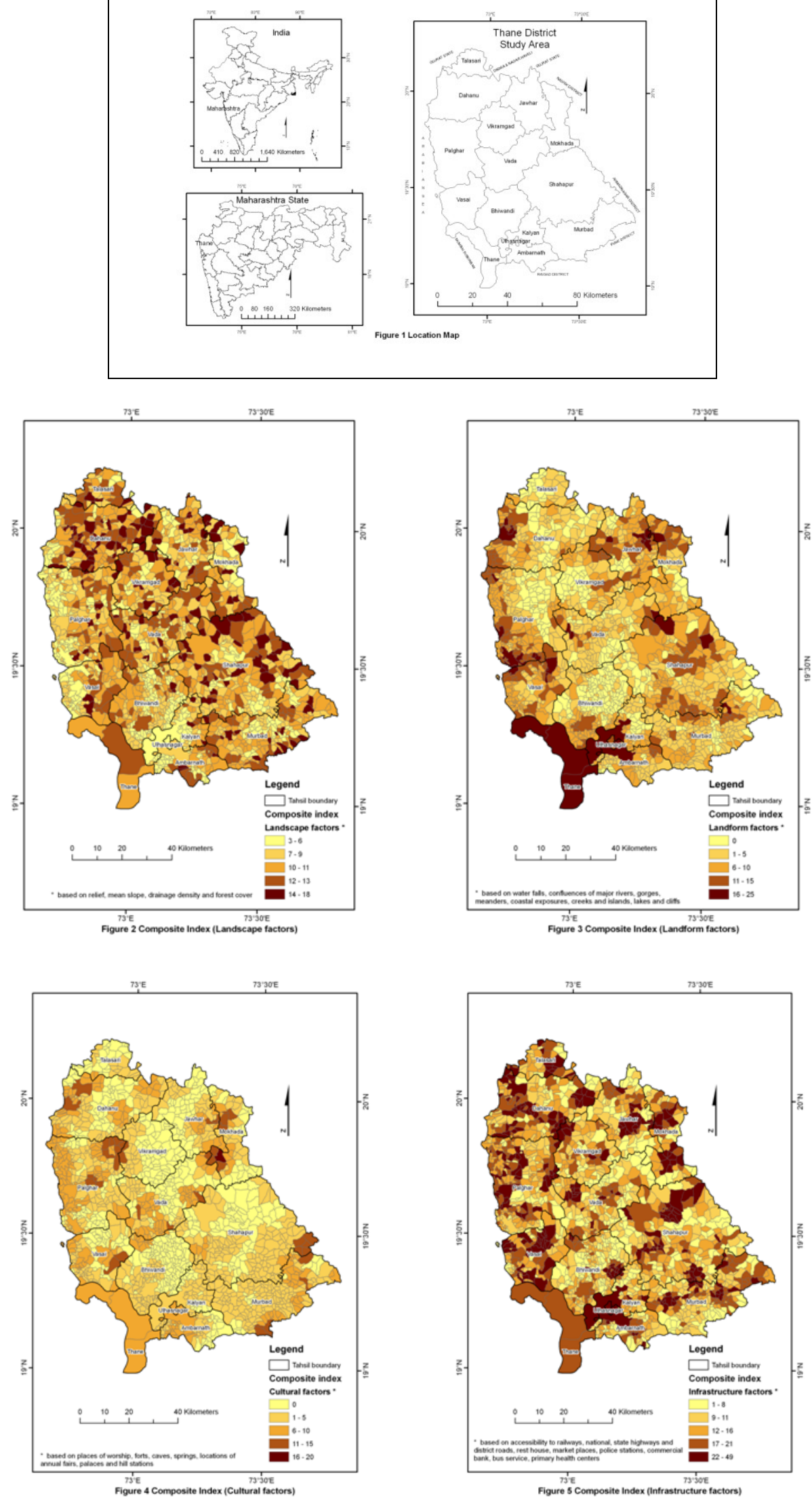


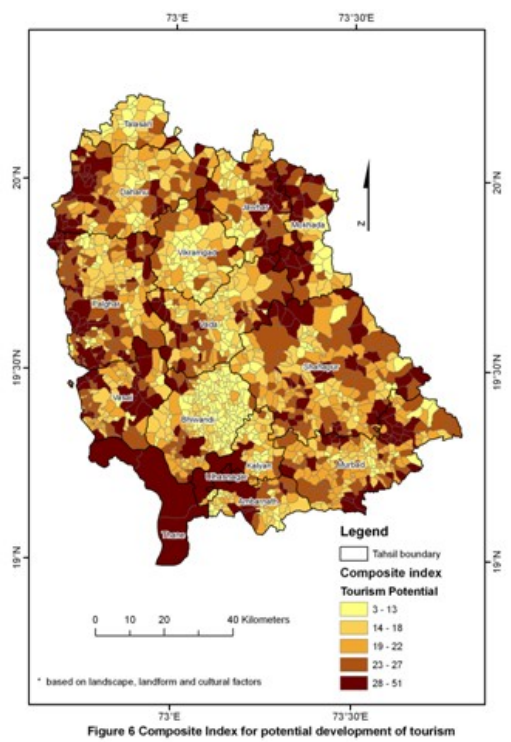

